Department of Pathophysiology,

Forensic Veterinary Medicine and Administration

University of Warmia and Mazury in Olsztyn, Poland

andrzej.dzikowski@uwm.edu.pl

DOI: $10.13166 / \mathrm{JMS} / 130064$

JOURNAL OF MODERN

SCIENCE TOM 2/45/2020,

S.121-141

ORCID iD: https://orcid.org/0000-0002-3223-7542

IRENEUSZ SOŁTYSZEWSKI

Department Cryminology and Crimanalistics,

University of Warmia and Mazury in Olsztyn, Poland

ireneusz.soltyszewski@uwm.edu.pl

ORCID iD: https://orcid.org/0000-0003-1128-8129

JUSTYNA KARAŹNIEWICZ

Department of Criminal Proceedings and executive criminal law University of Warmia and Mazury in Olsztyn, Poland

justynakarazniewicz@poczta.onet.pl

ORCID iD: https://orcid.org/0000-0003-2276-6640

JÓZEF SZAREK

Department of Pathophysiology, Forensic Veterinary Medicine and Administration

University of Warmia and Mazury in Olsztyn, Poland

szarek@uwm.edu.pl

\section{MARIUSZ Z. FELSMANN}

Centre for Veterinary Sciences,

Nicolaus Copernicus University, Toruń, Poland

felsmann.mariusz@wp.pl)

ORCID iD: https://orcid.org/0000-0002-7026-3215

BeAta Kosiba

Institute of Political Science,

University of Warmia and Mazury

in Olsztyn, Poland

beata.kosiba@uwm.edu.pl

ORCID iD: https://orcid.org/0000-0002-4956-6991

\title{
OWNERS' INFORMED CONSENT FOR A NECROPSY OF A COMPANION ANIMAL AS A CONFLICT- -REDUCING MEAN IN THE VETERINARY PRACTICE
}

\begin{abstract}
:
The authors' aim is not only to extend research, but also to assist in problemsolving actions in every-day veterinary practice. General ethical-and-legal provisions of conduct of veterinary surgeons are subject to the legal analysis and interpretation (literary, teleological and comparative methods) in terms of owner's consent for animal posthumous examination. The work's novelty reveals itself in the touch of the
\end{abstract}


issues of consent for a post-mortem examination of animals, and not for diagnostic tests, pharmacotherapy, and surgical treatment. Means reducing interhuman stress, legal claims, and moral conflicts are discussed; different case-types of irrelevance and relevance of such consent are revealed and described. Terms of valid informed consent for an animal necropsy, and its distinct points, which have not been described yet, are presented. The need of the valid informed consent is revealed.

KEYWORDS: animal cadaver, animal welfare, forensic veterinary medicine, posthumous, post-mortem

\section{INTRODUCTION}

Any human interaction concerning formal procedures could possibly give a rise to conflicts and claims, especially if it is of emotive nature, as attitude of owners towards their animals is (DeGraaf, 2005, 557-578, Morgan and McDonald, 2007, 165-179, Tannenbaum, 1993, 143-156). Postmortem examination of animals is one of such procedures. Contact points of moral philosophy and law applicable to consents for such procedures are, however, poorly researched and described in the literature on veterinary ethics - in contrast to consents for veterinary diagnostic tests and surgical operations (Brooks-Brownlie and Munro, 2016, 919-928). In terms of human autopsies, legal issues of family or statutory representative consent are well developed: in legal acts, judicature, legal doctrine, and literature (Nijhawan, 2013, 134-140). This cannot be stated for animal necropsies. Although all animal informed consent rules are profoundly modelled, established, and dependent on legal achievements of human medical law, not every such rule can be exerted for veterinary posthumous examinations. This is due to the sui generis legal status of human corpse, different form this of an animal cadaver, and distinct legal relations deceased - family or representatives - pathologist vs. animal cadaver - owner - veterinary pathologist. With regard to the owner's consent to carry out the animal necropsy, it should be pointed out: firstly, that it should be an informed consent, and, secondly, that the eventual requirement to obtain it, depends on the legal basis of the necropsy. Legal provisions shape the owner's situation and the significance of his will differently, depending on the subject, situation, premises, and legal grounds for carrying out a post-mortem examination. However 
miscellaneous laws do apply in different countries, the general schemes and general guidelines, consisting the 'ius commune' of the Western, civilian legal tradition (Zimmermann, 1990, passim), will be presented in the present argumentation. The normative analysis would be therefore carried out in isolation from particular legal systems and regimes, to avoid particularities, and emphasize the general trends.

Not only the common legal aspects shape the discussed problem, but also the common principles of medicine, including professional ethics. In many legal systems such ethical rules are incorporated to the official hierarchy of legal acts, e.g. as the Veterinary Surgeons' Ethical Code, and can be executed in court.

Nevertheless, every veterinarian should observe the same moral philosophy in this work, as every medical since the Antiquity swears the same general

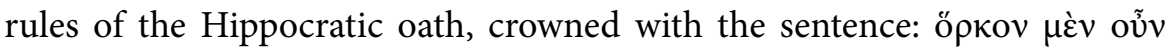

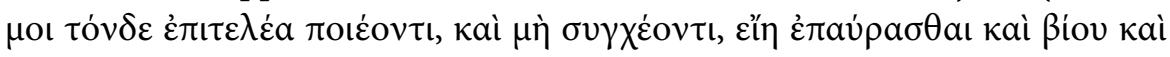

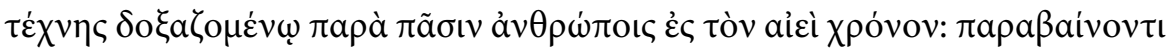

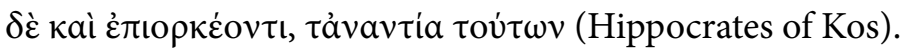

Veterinary surgeons are not only medicals, but also public trust professionals - responsible in terms of ethics and morality in an aboveaverage level, and therefore, they should strive to minimize interhuman tensions and disputes, including legal claims (Hernandez et al., 2018, 3-22, McDonough and McEven, 2016, 875-877, Ottinger et al., 2014, 459, Rollin, 2002,1144 , Rollin, 2004, 3-5). One of the possibilities is to obtain the owner's express consent for performance of the necropsy.

Apart from the established rules of professional ethics, also the human, humane, and humanistic aspects of animal necropsies shall be contemplated. For many owners, and members of their families, especially children, the death of an animal is an emotional experience. Furthermore, all human deeds can be considered in terms of morality, whether based on religion, on philosophy, or on the natural law.

As briefly stated by Ashall et al. (2008, 247-258): 'The consent procedure in the veterinary setting is (...) an ethical pivot point, where multiple competing interests must be weighed to determine a defensible course of action. (...) a veterinary surgeon's role (...) needs to be considered in light of the complex 
ethical and legal obligations that veterinary surgeons hold, and which are played out during the veterinary consent process'.

\section{Methods}

Legal and moral norms related to veterinary necropsies and owners' consent for them were analyzed according to literary, teleological and comparative methods of interpretation. The method of the literature review was used (the basic research technique used - searching the Scopus database in terms of frequency of citations), merged with an in-depth description of the process of definition developing (necropsy, veterinary practice).

\section{RESUlts AND Discussion}

\section{Legal status of animals}

There is an animal protection tendency observed in many legal systems to point out that an animal, being a living creature capable of suffering, is not a thing. An example is the European Convention for the Protection of Pet Animals (1987). More traditional views abstain from, or postpone, such novelties, as these are rather emotionally charged postulates, not strict legislation.

Even if there is a dereificatory statement present in the animal protection rules, it is no applicable to the civil law, where the normative provisions concerning things (e.g. law of sales) should be applied. It should not be a direct application, but rather an appropriate, taking into account the specificity of animals: they are not things, but treated as if they were; there is no right of ownership, but a special property right similar to ownership, etc. It should be, however, noted that also in the traditional approach, animals require different legal treatment than other objects, due to their nature and specific characteristics.

Regardless of whether animals are treated as movable things or not, the principles of animal protection can be easily realized without such reservations (e.g. People v. Spencer, 1921, People v. Odenwalds, 1930). The authors postpone themselves from any ideas concerning 'animal rights' sensu stricto, 
as animals - according to the principles of logic, and modern discoveries of science, incl. neurobiology - cannot be legal subjects, and therefore are, a special kind of objects, but still - objects (Goettel, 2013, passim, Passantino et al., 2011, 128-134). Instead of creating illogical, unacceptable legal entities, one should focus on the obligations of men, in relation to animals.

The content, and ratio of the animal protection provisions clearly show that these regulations apply only animals alive. This means that the dead animal (corpse) is a thing (Danecka and Radecki, 2014, 132-163, Muellerova and Stejskal, 2013, passim, Passantino et al., 2011, 128-134, Rudnicki and Trzaskowski, 2014, art. 45). Nevertheless, for many of the animal owners, it is difficult to agree with it. Therefore, the most important thing when assessing the importance of the owner's consent is to determine the rights of the owner of the corpses.

The owner has extensive authority to use things with the exclusion of others. The limits of this use are determined by the statutory and customary law, principles of good manners and good faith, rules of the social coexistence, and socio-economic purpose of the owner's rights (to avoid the abuse of rights). Ethical-and-legal standards, though different than in case of veterinary professionals, apply also to other legal subjects, i.a. animal owners.

It should be emphasized that the owner is entitled to full dominion over the thing, including the rights to possess, to use, and to dispose of an item (ius possidendi, ius utendi, ius disponendi), but does not have any right to abuse his or hers animal (Fras and Habdas, 2018, art. 126-352).

In the scope of the civilian provisions, no doubts raise that the owner is the sole disposer of the animal cadaver. He can delegate his authority to a third person (proxy). Statutory law can also authorize other person or official entities to act some aspects of the ownership rights.

The purpose of the informed consent can be indicated in many ways, depending on the procedure under consideration, subject of the procedure, entity authorized to agree, and differs in human and in animals - for it does not protect any interests of an animal itself, but those of the owner (Ashall et al., 2011, 247-258, Beauchamp and Childress, 2013, passim, Flemming and Scott, 2004, 1436). The initial economic purpose is observed to be less important nowadays, and new dimensions like emotional values arise 
(Fettman and Rollin, 2002, 1386). In the literature, however, a tendency can be seen to ignore the cases of post-mortem examinations, and analyze only animal treatment. Animals, in contrast to humans, cannot make their own agreements or decisions in a civilian way, and are nonautonomous. Some owners tend to perform veterinary interventions being not in the best interest of the animal, which cannot occur in case of incapable men (Ashall et al., 2011, 247-258, Downie and Randall, 1997, 219-231, Palmer et al., 2012, 153-172).

The idea of the veterinarian's prevailing obligation to protect the animal health and welfare (animal advocacy), as the major professional ethical value, is present in some legal systems (British Veterinary Association, 2016), while in other states - the major value is the good of mankind. According to the first of the presented scopes, the basis of veterinary procedures can be solely the animal's good, and veterinary ethical obligations could overrule the owner's rights (Ashall et al., 2011, 247-258, British Veterinary Association, 2016). This concept, however, has no application to the posthumous examination. One could, therefore, construe that this idea has only strictly limited application (to animals alive), or is illogical and not well-based. Such a problem does not occur when using the second presented attitude.

As it has been already stated, dead animals are things. The only difference, comparing to other objects, is the emotive attitude of their owners. It should be observed that different legal and moral rules, based on philosophical and religious traditions of the Christian world, apply to human corpse (Drayton, 2013, 264-281, Jones, 2000, passim, Lavelle-Jones et al., 1993, 885).

The purpose of the informed consent is, therefore, the protection of: in human - the personal autonomy, including protection of incapable individuals against malefices; in human corpse - the 'blessed memory' of the deceased, incl. religious beliefs and respect to the person who was, as well as the emotional status of the family; in animals - the owner's interests in protecting the animal's value (not merely economic, but also emotional etc.) to themselves, and not for animals; in animal cadaver - the owner's emotional interests. 
It should be stated that such a research result provides adequate explanation for the question: why do people rise arguments and legal claims in case of a dead animal's section? It is, tribus verbis and extremely simplifying, the psycho-emotional reaction to a loss.

\section{OFFICIAL (COURT AND ADMINISTRATIVE) NECROPSIES}

Entitlement to perform consent, according to the type of postmortem examinations, determines also legal and ethical standards applicable. It is necessary to distinguish situations in which such an activity is to be carried out on behalf of the state authorities, and is based on provisions giving them the right to order obligatory forensic necropsies (Forbes, 2004, 503-506). Such powers are attributed to organs conducting criminal proceedings, such as courts, prosecutors, or the police (Lane and Vercler, 2016, 771-778, Szarek, 2005, passim). Due to the commitment of a felony or a misdemeanor, resulting in the death of an animal, its cadaver may be a source of evidence, providing relevant information in the criminal case.

This may apply to a variety of offenses, in particular those in which the animal (his life or health) was subject to the perpetrator's attack (e.g. poisoning, animal cruelty), as well as in cases in which the animal was a participant of an incident, in connection with which criminal proceedings are conducted (e.g. road accidents involving animals, dog bites) (Gerdin and McDonough, 2013, 994-1006).

In such situations, in the framework of criminal proceedings, the court, prosecutor or the police, could issue a decision on appointment of a veterinary expert, if determining the relevant circumstances requires special veterinary knowledge and information (Forbes, 2004, 503-506). The expert should draw up an opinion based on the conducted forensic posthumous examination (Babińska et al., 2017, 347-351). It should be emphasized that the experts' specialization should cover the narrow field of forensic veterinary medicine, although in many countries there are no such expert specializations, and any veterinary surgeon is authorized to carry out necropsies, and issue opinions (Harris, 1998, 176-181, Listos et al., 2015, 84-89). 
In such cases, the animal cadaver is an evidence, and remains at the disposal of the prosecutor or the court. The decision of the authority conducting the proceedings on the part of the court veterinary expert is a ruling one, and therefore it does not require the owner's consent. In addition, in case of criminal events, section is often necessary, even if X-ray and CT scans were previously performed (Felsmann and Gogulski, 2018, 405-408).

If the owner would be the possessor of such cadaver, even if he or she does not agree to the procedure - this lack of consent is legally irrelevant. The owner is obliged to issue the animal corpse on the instructions of the authority, and in the case of refusal of a voluntary release, the state authority is entitled to compulsory, forcible collection.

It is also worth pointing out that the prosecutor pragmatics rules of internal administration allow to replace court expert opinions (issued by a person or an entity appointed as an expert in the specific criminal proceeding) with the official documents that have been prepared by not-appointed experts (persons with special knowledge). A condition for resignation from the appointment of a court expert is the recognition that their completeness and reliability is in doubt.

Similar rules, according to which the owner's consent to conduct the section is not required, is the case of the administrative sanitary necropsy, carried out as part of an epizootiological investigation in connection with the control, and combat of infectious diseases. Legal norms of each state, based on the current veterinary knowledge, should define the rules for combating infectious animal diseases, including zoonoses. If there is a suspicion of an infectious disease, the animal holder is obliged, i.a. to notify the competent authorities (e.g. officers of the veterinary state authorities), and provide the animal or its' corpse for veterinary examinations, tests or treatments, as well as to provide assistance in implementation of the procedures.

Significant rights can be granted to the state veterinary officers who, in order to eradicate infectious animal diseases, may issue a decision ordering the necropsy of animals with sampling for laboratory tests. In such cases the owner is obliged to release the cadaver in order to carry out the necessary research to confirm or deny the occurrence of the disease, and to obtain other information. Consequently, owner's consent or lack thereof, has no legal significance, and its obtaining is not a condition for carrying out the discussed activity. 


\section{UNOFFICIAL NECROPSIES}

Different rules should be applied in the cases of a diagnostic section. The diagnostic necropsy is neither carried out, nor ordered by the body conducting criminal proceedings in connection with the suspicion of a crime commitment, nor as a part of procedures of infectious diseases combat. It is an examination performed to determine the cause of death, and the pathogenesis (DeLay, 2016, 1078-1086, McDonough and McEven, 2016, 875-877).

From the teleologic point of view, the necropsy is justified and purposeful in any situation in which the veterinary surgeon has a reasonable grounds to expect that the outcome of the post-mortem examination could and would determine the causa mortis proxima, and the factors that led to it. This is especially desirable in relation to animals killed during veterinary surgeries or in an event of an emergency, and sudden death.

Depending on the situation, both the owner, and the veterinary surgeon responsible for the animal's treatment, may be interested in the performance, and results of the necropsy. In the event of a conflict between the veterinarian and the owner, the will of the latter should prevail.

The current legal regulations mostly do not indicate expressis verbis whether, and in which situations, the diagnostic veterinary necropsy is subject to the consent of the owner, and in what form and time such consent should be given. Solutions to this problem should be sought in veterinary professional standards or legislation, as well as in the common civilian regulations.

Reference should be made to the rules for the veterinary services. The concept of a veterinary service includes performance not only of diagnostic tests, treatment sensu stricto, and surgical procedures, but also of necropsies. It is a civilian contract, mostly covered by the concept of the obligation of conduct. The owner (guardian, possessor, holder) of an animal to whom the veterinary service is provided, has the right to obtain information about the animal's health, treatment methods, foreseeable consequences of their use or omission, and the anticipated costs (DeGraaf, 2005, 557-578, Federation of Veterinarians of Europe).

The owner's consent is always indispensable, although it can be expressed in many different ways. The veterinary surgeon may require 
a written permission before commencing the veterinary service. This is related to the fact that the veterinary profession is a privately-paid job, and each service is provided for a contractual fee - the costs are borne by the owner. The possibility of requesting the written consent is, above all, of importance in determining the scope of the service ordered by the owner and the related remuneration - the contractual fee and other costs (Royal College of Veterinary Surgeons, 2014). It consists also the evidence of the consent, provide protection against legal claims not only for veterinary surgeons, but also for animal's owners, and help in risk management (Flemming and Scott, 2004, 1436, Jackson, 2010, passim, Martin, 2006, 45, Royal College of Veterinary Surgeons, 2016). The signed consent form consists a part of veterinary clinical records, and its copy should be provided for the animal's owner.

If there is a typical consent form used in the veterinary practice, it is advisable, in case of procedures conducted on animals alive, to leave a blank space to mention specific information on the treatment under consideration, and specific agreements of the parties. This practice is of lower importance in case of post-mortem examinations, due to their general similarity, but could be eventually observed accordingly.

The veterinarian should ensure not only the state of ownership, but also the minimal age of the person from whom the consent is to be obtained.

In addition to the scope of veterinary professional standards, there remain situations in which the owner is not interested, and does not request the necropsy, while such a need is recognized by the veterinarian. In such cases, reference should be made solely to the provisions of civil law. Thus, the owner's (as the sole disposer) consent is inevitable. Performance of the necropsy against the owner's will constitutes therefore a violation of the owner's rights, and can be a crime.

If a dead animal is in the possession of a veterinary surgeon (the person, who actually wields the thing), the owner may request to release the corpse. Any arbitrary decision of the post-mortem examination without the owner's consent (e.g. if the owner does not request a corpse, incurring the costs of utilization through the veterinary clinic), should be treated - according to the proper civil statute - as a violation of property rights, otherwise 
than by depriving the owner of the actual control over the thing. In such a situation, the owner is entitled to a claim to cease infringements, and thus to nonperformance of the post-mortem examination. From the above considerations it should be emphasized that the diagnostic necropsy against the will of the owner is unacceptable, and illegal.

However, the way in which the owner should communicate his will should be analyzed: two interpretational solutions are possible in this regard.

Firstly, a presumption of the owner's consent for acts performed with the corpse by the veterinary surgeon, in possession of whom this cadaver is. It should be assumed that the obstacle to the necropsy is the owner's express objection. A similar solution was adopted for human autopsies, because (apart from the cases of forensic autopsies ordered by the court, related to the prevention and eradication of infectious diseases, and the situation of an ambiguous cause of death) the patient's corpse is not subjected to the postmortem examination if the statutory representative or family of the deceased (or the deceased him- or herself prior to death) has objected.

It seems, however, that the analogous application of the discussed rules to the animal necropsy is not appropriate. Acceptance of the general presumed consent, and the possibility of objection, seems obvious, since no expression of will after death is possible. Moreover, human corpse is not a thing, is extra commercium, and the statutory representative of the deceased is not the cadaver's owner.

Secondly, an inevitability of obtaining the owner's informed consent to carry out the necropsy by the veterinarian, expressed in a written form. In this case, the owner of a corpse has the opportunity to express his or her will at the moment of animal death or shortly after, if the veterinary physician wants to carry out the posthumous examination.

With regard to necropsies, the adoption of the second solution seems more reasonable, and can be derived from the compulsory character of the compliance with the owner's will. This solution corresponds to the abovementioned provisions referring to the obligation to inform the owner about actions taken, and to the legal possibility of requesting written consent for these deeds. Therefore, the veterinarian should inform the owner and obtain his acquiescence, preferably in writing. This form provides protection against potential conflicts and claims, and prevents them. 
In human medical law there is a significant difference between the ownconsent for therapy (diagnostics, surgical or pharmacologic treatment), and the consent of a third party to perform the autopsy. In veterinary medical law such a difference cannot have place, as animals cannot decide for the therapy of themselves even if they are alive.

Several contact points and similarities can be observed between veterinary consent sensu largo, and the consent of a tutor, a curator or a proxy acting on behalf of a minor, incapacitated, or disabled person (Ashall et al., 2008, 247-258).

This is especially true for new trends of animal welfare protection, according to which animal's owner is obliged (in a moral rather than legal way) to act for the sake of animal's health rather than for his own good - even if this animal is treated by the law as a thing. It is an approach to the situation of people under wardship or tutelage - the person entitled to act in somebodies name as a statutory representative cannot worsen his pupil's legal situation and health state (Ashall et al., 2008, 247-258, Downie and Randall, 1997, 219-231, Palmer et al., 2012, 153-172).

It should be noted that sections in course of scientific experiments and veterinary higher education are also performed (consent of the ethical committee is then required).

\section{OWNER'S INFORMED CONSENT, LEGAL AND ETHICAL STANDARDS APPLICABLE}

Legal rules of informed consent for medical procedures are a relatively new, but already well-established branch of the modern civil law, and include sundry types of procedures (e.g. diagnostics, drugs application, surgeries, autopsies, euthanasia, transplantations, and organ donations), and various entities authorized to perform the consent (e.g. patient, statutory representatives, family, courts, police, and prosecutors) (McDermott, 2003, 804-806). They, however, still rise doubts, discussion, and public disquiet (McDermott, 2003, 804-806).

For obtaining the informed consent for human autopsy, many - still evolving - principles are recommended in the literature and by professional 
bodies in case of unofficial (i.e. not commanded by the state authorities) examinations, but not every recommendation is legally bounding (Knowles, 2001, 215-227, Laing, 2004, 247-254, Lane and Vercler, 2016, 771-778, McDermott, 2003, 804-806, McHaffie et al., 2001, 4-7, Royal College of Pathologists, 2000, Royal College of Pathologists, 2002).

As an example can serve the pre-autopsy consultation, explanation, discussion of the consultant (physician treating the patient (the deceased), principal clinician, pathologist) with the family of the deceased, treated as an important part of the procedure - aimed not only to obtain formal consent, but to clarify and solve all doubts (McDermott, 2003, 804-806). This view on the way of obtaining consent not likely to become a legal obligation, but rather it should maintain, and be treated alike a good medical practice. The rules presented in the literature on human posthumous examinations are deeply humane, they are, however, not the typical rules of medical law, but recommendations for the best medical practice. For strict legal scope it is only necessary to gain the consent of an authorized person or entity, preferably in written (as a source material).

Some of these achievements are applicable to veterinary medicine (Ashall et al., 2008, 247-258). There are several principles, that can be used pointblank, but most of the rules can be used only accordingly, while the other cannot be used for veterinary practice.

The qualities of the consent itself can be used without deeper modifications, apart from the notorious fact, that it is not the family of the deceased, but the animal's owner to decide (Ashall et al 2008). Legal nature of the informed consent is well-described in the doctrine, and is applicable both in human and veterinary medicine, not only for procedure carried out with the patient alive, but also as death occurs (Ashall et al 2008). Informed consent is a crucial element of every civilian contract. This information should be: complete, anticipative, sufficient, plain, transparent, comprehensible, precise, unambiguous, understandable (Byrne et al., 1988, 839, Lavelle-Jones et al., 1993, 885, Royal College of Veterinary Surgeons, 2014, Stanley et al., 1998, 788-791). Language used should be intelligible to the clients knowledge, age, and psycho-emotional state. Assumption of the owner's knowledge or wealth should be excluded (LeBail, 2003, McDermott, 2003, 804-806). 
Information should cover not only the foregoing procedure itself, but also its purpose, prospected benefits, outcomes, and aftermaths, as well as fees, and costs. The cost statement, including payment obligation (and, if applicable, diagnostic tests fee limits) should consist a part of the written consent form.

The discussed explanation should be given, preferably, by the veterinarian who conducted the therapy or the pathologist who would conduct the necropsy. In some legal systems, for teleological and practical reasons, it is possible to delegate a suitably-trained person of a sufficient knowledge, e.g. veterinary nurse, to carry out the conversation and provide necessary information. Every time, however, the person responsible is the veterinary surgeon delegating his or hers powers.

No doubts arise that informing about and obtaining consent for the postmortem examination, and its type, is necessary. This cannot be stated about the tendency observed in making an agreement taking into account medical standards and needs, as well as family views and beliefs (McDermott, 2003, 804806). Human corpse is treated in relation to the person deceased, and, as a sui generis object par excellence is subject to most diligent caution (Jones, 2000, passim). Concerning animal cadaver situation is very different. Although many people are very emotive about their animal's death and suffer pain, no general and worldwide rule can be observed to compare such a loss with the human death. Religious and philosophic views are therefore less relevant, or even irrelevant in this case. Moreover, dead animals are subject to utilization or recycling procedures defined by the law; in some countries human-like burial of animals is illegal, in many others - it is considered as eccentricity or exaggeration.

On the other hand, a proper conversation, comprehensible and intelligible explanation, and humane discussion of the veterinarian with the owner and his or hers family, especially children, would facilitate the consent obtainment, and thus eliminate complaints, misunderstandings, and legal claims.

Both the client and the veterinarian should attempt to understood themselves properly. This is the very first premise to perform a valid informed consent, and a valid contractual agreement. This is not only a pium desiderium, but an ethical-and-legal obligation for veterinary surgeons - stated not only by the rules of professional moral philosophy, but also by the contractual principle of good will. 
The veterinary surgeon should therefore make his client to be in a position to perform the informed consent.

Animal's owner should have the opportunity and sufficient time to gain information about the posthumous examination procedure, ask questions, understand it properly, consider it, and make a free, voluntary decision (Ashall et al., 2008, 247-258, Bateman, 2007, 109-121, Delcarmen and Joffe, 2005, 636-641, LeBail, 2003). Giving consent should be the owner's choice - not the veterinarian's, and therefore it is the owner to enhance his or hers own opinion on the need of the necropsy performance. The specialist should, however, put an emphasis on the depicted benefits and expected outcomes (test results, incl. diagnosis), gained via the necropsy performance, bearing in mind possible disadvantages.

There is a tendency observed in human medical law, to perform a procedure informing about and obtaining consent for the organ or tissue retention for further diagnostics, rendering of organs or tissues, and archiving of waxembedded tissues (McDermott, 2003, 804-806). Specific written agreements for any whole-organ retention, and for any educational or research usage, are recommended. This rule is partly applicable to veterinary medicine.

Ethical standards in science force all researchers to act uniformly and equally-carefully worldwide (Magalhaes-Sant'Ana, 2014, 592-597, Morgan and McDonald, 2007, 165-179), and to enforce animal welfare. It is, therefore, inevitable to obtain owner's consent for any research procedure (it can consist a part of the general consent form, the owner should be informed of this aspect).

For current development of the veterinary standards, authors observe no need for such agreements for animal organ retention or rendering, for this practice evolved on the basis of special treatment of human cadaver. Moreover, tissue or organ retention for further tests is in many cases crucial for the diagnosis, and consists a part of a normal section procedure lege artis. Consent of the owner for the necropsy covers therefore also this action, but one should remember that the owner should be informed of this specific aspect.

There are several dissimilarities of the necropsy consent, compared to the standard obtainment of the treatment consent in animals (and in human). Necropsy leaves no place for 'alternative reasonable treatment options' - but 
there are still alternatives, firstly, to forbear from post-mortem examination, secondly, to reduce the range of examination, especially to abandon additional tests, e.g. microscopic, histologic, microbiological, or toxicological tests. Neither are in case under discussion medical risks, side effects, nor medical errors sensu stricto possible to occur. These facts have not been depicted in the literature and doctrine yet, as the authors emphasized and elaborated only animal treatment consent obtainment, and not the necropsy consent.

Veterinarian, as a public health guard, have many ethical responsibilities, i.a. should inform the client of any possible public health hazards connected with the animal dead, incl. infectious diseases, especially zoonoses (LeBail, 2003).

Professional ethical norms in connection with the civil law are ius semidispositivum (semiimperativum), the parties may regulate their rights and obligations in a manner different from the statutory provisions, if such changes are more favorable, e.g. provide higher ethical standards, strengthen ownership rights, and intensify animal protection.

Every case of disconsent / lack of consent of the owner should be noted in the veterinary documentation, clinical records (not only mere fact, but also reasoning), and confirmed by the date, veterinary surgeon's signature, and seal. The same rule applies to situations in which: the client refuses to discuss, does not want to know about the possible costs, the consent is limited, withheld or qualified, as well as if any associated costs or specific wishes arise.

\section{Conclusions}

It should be stressed, that every veterinarian is a member of a profession characterized by the public trust and reliance, and therefore his or hers deeds should be a model of an above-average ethical behavior and lawful conduct. Common general legal and ethical standards can be derived for veterinary surgeons worldwide. Ethical behavior of veterinarians impacts animal welfare and enforces proper course of post-mortem examinations.

The present analysis reveals that in the case of the forensic veterinary necropsies (carried out at the ordinance of the court, prosecutor or the police), and administrative-sanitary necropsies, consent of the owner is not 
required, and irrelevant. On the other hand, in case of any the diagnostic section, the veterinary surgeon is required to obtain the owner's express, informed consent, preferably in written.

Valid informed consent provides protection against legal claims for both veterinarians and owners. Among several criteria to be met, the most important are: entitled persons to perform consent, and to provide adequate, intelligible information and explanation, contractual freedom. Also the proper conversation and discussion, aimed to produce mutual understanding and comprehension, can reduce owners' claims.

The research revealed several distinct points of the animal necropsy consent, which have not been described yet, i.a. different legal nature and particular purpose of the consent than in other cases; special character of the animal cadaver and the owner's rights related to it; as well as lack of medical errors sensu stricto and risks.

The study showed, that particular ethical responsibilities of the veterinarians, shape the semi-dispositive legal situation of obtainment of the informed consent for animal posthumous examination, together with the civilian norms. Informed consent procedures for animal necropsy aim to protect not only animals, but also ethical and legal interests of both owners and veterinary surgeons. For owners, it is mostly about the conscious, dispassionate surviving a loss; for professionals - to act according to the veterinary medical art and ethics. The joint comprehension and balance of the interests of both sides would allow to eradicate possible mutual accusations and claims, as well as foster the building of trust between animal owners and veterinarians.

\section{Bibliography}

Ashall, V., Millar, K.M., Hobson-West, P. (2008). Informed consent in veterinary medicine: Ethical implications for the profession and the animal 'patient'. Food Ethics 1 (3), pp. 247-258. ISSN 2364-6853.

Babińska, I., Kusiak, D., Szarek, J., Lis, A., Gulda, D., Felsmann, M.Z., Łyko, A., Maciejewska, M., Popławski, K., Szweda, M. (2017). Veterinary expert opinions on conflicts involving dogs and cats in Poland. International Journal of Forensic Science \& Pathology 5 (3), pp. 347-351. ISSN 2332-287X. 
Bateman, S.W. (2007). Communication in the veterinary emergency setting. Veterinary Clinics: Small Animal Practice 37, pp. 109-121. https://doi.org/10.1016/j. cvsm.2006.09.005.

Beauchamp, T.L. and Childress, J.F. (2013). Principles of biomedical ethics. University Press: Oxford. ISBN 9780199924585.

Brooks-Brownlie, H.W. and Munro, R. (2016). The veterinary forensic necropsy: a review of procedures and protocols. Veterinary Pathology 53 (5), pp. 919-928. ISSN 0300-9858.

British Veterinary Association (2016). Vets speaking for animal welfare: British Veterinary Association animal welfare strategy.

Byrne, D.J., Napier, A., Cuschieri, A. (1988). How informed is signed consent? British Medical Journal 296, p. 839. ISSN 0959-8138.

Danecka, D. and Radecki, W. (2014). Legal Protection of Animals in the Czech Republic in comparison with the Polish Law. Przegląd Prawa Ochrony Środowiska 3, pp. 132-163. ISSN 2080-9506.

DeGraaf, G. (2005). Veterinarian's discourses on animals and clients. Journal of Agricultural and Environmental Ethics 18, pp. 557-578. ISSN 1187-7863.

DeLay, J. (2016). Perianesthetic mortality in domestic animals: A retrospective study of postmortem lesions and review of autopsy procedures. Veterinary Pathology 53 (5), pp. 1078-1086. ISSN 0300-9858.

Delcarmen, M.G. and Joffe, S. (2005). Informed consent for medical treatment and research: A review. Oncologist 10, pp. 636-641. ISSN 1549-490X.

Downie, R.S. and Randall, F. (1997). Parenting and the best interests of minors. Journal of Medicine and Philosophy 22, pp. 219-231. ISSN 0360-5310.

Drayton, J. (2013). Bodies-in-life/bodies-in-death: social work, coronial autopsies and the bonds of identity. British Journal of Social Work 43 (2), pp. 264-281. ISSN 1463 $263 \mathrm{X}$.

European Convention for the Protection of Pet Animals 1987. Strasbourg, ETS No.125

Federation of Veterinarians of Europe. European Veterinary Code of Conduct 2.2.

Felsmann, M.Z. and Gogulski, M. (2018). Post-mortem diagnosis of gunshot injuries in an osprey: A case report. Medycyna Weterynaryjna 74 (6), pp. 405-408. ISSN 0025-8628.

Fettman, M.J. and Rollin, B.E. (2002). Modern elements of informed consent for general veterinary practitioners. JAVMA 221 (10), p. 1386. ISSN 0003-1488. 
Flemming, D. and Scott, J.F. (2004). The informed consent doctrine: What veterinarians should tell their clients. JAVMA 221 (9), p. 1436. ISSN 0003-1488.

Forbes, N. (2004). An exacting science: the veterinary surgeon as expert witness. In Practice 26, pp. 503-506. ISSN 2042-7689.

Fras, M. and Habdas, M. (2018). Art. 126-352. in: Kidyba, A. (ed.) Kodeks cywilny. Komentarz. II. Własność i inne prawa rzeczowe. Lex Wolters-Kluwer: Warszawa.

Gerdin, J.A. and McDonough, S.P. (2013). Forensic pathology of companion animal abuse and neglect. Veterinary Pathology 50, pp. 994-1006. ISSN 0300-9858.

Goettel, M. (2013). Sytuacja zwierzęcia w prawie cywilnym. Lex Wolters-Kulwer: Warszawa. ISBN 9788326443756.

Harris, J.M. (1998). The role of the practicing veterinarian as an expert witness. Seminars in Avian and Exotic Pet Medicine 7, pp. 176-181. ISSN 1055-937X.

Hernandez, E., Fawcett, A., Brouwer, E., Rau, J., Turner, P.V. (2018). Speaking up: Veterinary ethical responsibilities and animal welfare issues in everyday practice. Animals 15 (8), pp. 3-22. ISSN 2076-2615.

Jackson, E. (2010). Medical law. University Press: Oxford. ISBN 9780198825845.

Jones, D.G. (2000). Speaking for the dead: Cadavers in biology and medicine. Ashgate: Farnham. ISBN 9780754620730.

Khiani, R., Shingler, S., Hasleton, P. (2003). Consent for autopsy. Journal of the Royal Society of Medicine 96 (1), 53. ISSN 0959-5287.

Knowles, D. (2001). Parent's consent to the removal and retention of organs. Journal of Applied Philosophy 18, pp. 215-227. ISSN 0264-3758.

Laing, I.A. (2004). Clinical aspects of neonatal death and autopsy. Seminars in Neonatology 9 (4), pp. 247-254. ISSN 1084-2756.

Lane, M. and Vercler, Ch.J. (2016). Is consent to autopsy necessary? Cartesian dualism in medicine and its limitations. AMA Journal of Ethics 18 (8), pp. 771-778. ISSN 2376-6980.

Lavelle-Jones, C., Byrne, D.J., Rice, P., Cuschieri, A. (1993). Factors affecting quality of informed consent. British Medical Journal 306, p. 885. ISSN 0959-8138.

LeBail, L. (2003). La mort de l'animal de compagnie. Thesis, Ecole Nationale Veterinaire, Alfort.

Listos, P., Gryzińska, M., Kowalczyk, M. (2015). Analysis of cases of forensic veterinary opinions produced in a research and teaching unit. Journal of Forensic and Legal Medicine 36, pp. 84-89. ISSN 1752-928X. 
Magalhaes-Sant'Ana, M. (2014). Ethics teaching in European veterinary schools: A qualitative case study. Veterinary Record 175, pp. 592-597. ISSN 2042-7670.

Martin, E.A. (2006). Managing client communication for effective practice: What skills should veterinary graduates have acquired for success? Journal of Veterinary Medical Education 33 (1), p. 45.ISSN 0748-321X.

McDermott, M.B. (2003). Obtaining consent for autopsy. British Medical Journal 327 (7418), pp. 804-806. ISSN 0959-8138.

McDonough, S.P. and McEven, B.J. (2016). Veterinary forensic pathology: The search for true. Veterinary Pathology 53 (5), pp. 875-877. ISSN 0300-9858.

McHaffie, H.E., Fowlie, P.W., Hume, R., Laing, I.A., Lloyd, D.J., Lyon, A.J. (2001). Consent to autopsy for neonates. Archives of Disease in Childhood: Fetal \& Neonatal 85 (1), pp. 4-7. ISSN 0003-9888.

Morgan, C.A. and McDonald, M. (2007). Ethical dilemmas in veterinary medicine. Veterinary Clinics: Small Animal Practice 37, pp. 165-179. https://doi.org/10.1016/j. cvsm.2006.09.005.

Muellerova, H. and Stejskal, V. (2013). Ochrana zvirat v pravu. Academia: Praha. ISBN 9788020023179.

Nijhawan, L.P., Janodia, M.D., Muddukrishna, B.S., Bhat, K.M., Bairy, K.L., Udupa, N., Musmade, P.B. (2013). Informed consent: Issues and challenges. Journal of Advanced Pharmaceutical Technology \& Research 4 (3), pp. 134-140. ISSN 0976-2094.

Ottinger, T., Rasmusson, B., Segerstad, C.H., Merck, M., Goot, F.V., Olsén, L., GavierWidén, D. (2014). Forensic veterinary pathology, today's situation and perspectives. Veterinary Record 175 (18), p. 459. ISSN 0042-4900.

Palmer, C., Corr, S., Sandoe, P. (2012). Inconvenient desires: Should we routinely neuter companion animals? Anthrozoos 25, pp. 153-172. ISSN 0892-7936.

Passantino, A., Quartarone, V., Russo, M. (2011). Informed consent in veterinary medicine: Legal and medical perspectives in Italy. Open Journal of Animal Sciences 1, pp. 128-134. ISSN 2161-7597.

Rollin, B.E. (2002). The use and abuse of Aesculapian authority in veterinary medicine. JAVMA 20 (8), p. 1144. ISSN 0003-1488.

Rollin, B.E. (2004). Ethics in veterinary practice. SVME News 10 (2), pp. 3-5.

Royal College of Pathologists (2000). Guidelines for the retention of tissues and organs at post mortem examination.

Royal College of Pathologists (2002). Guidelines on autopsy practice. 
Royal College of Veterinary Surgeons (2014). Code of professional conduct for veterinary surgeons.

Royal College of Veterinary Surgeons (2016). Ethics review panel.

Rudnicki, S. and Trzaskowski, R. (2014). Art. 45. in: Gudowski, J. (ed.) Kodeks cywilny. Komentarz. Księga pierwsza. Cz. ogólna. Lexis Nexis: Warszawa.

Singer, P. (1995). Rethinking life and death: The collapse of our traditional ethics. University Press: Oxford. ISBN 0192861840.

Stanley, B.M., Walters. D.J., Maddern, G.J. (1998). Informed consent: How much information is enough? ANZ Journal of Surgery 68, pp. 788-791. ISSN 1445-1433.

Szarek, J. (2005). Lekarz weterynarii jako biegly. University Press: Olsztyn. ISBN 8372994137.

Tannenbaum, J. (1993). Veterinary medical ethics: a focus of conflicting interests. Journal of Social Issues 49 (1), pp. 143-156. ISSN 0022-4537.

Williams, A.T., Morris. D., Patel, N.K. (2002). Pathologists' views on consent for autopsy. Journal of the Royal Society of Medicine 95, pp. 547-548. ISSN 0959-5287.

Zimmermann, R. (1990). Law of Obligations: Roman Foundations of the Civilian Tradition. Juta \& Co.: Cape Town-Wetton-Johannesburg. ISBN 9780198764267.

Zink, S. and Wertlieb, S. (2006). A study of the presumptive approach to consent for organ donation: a new solution to an old problem. Critical Care Nurse 26 (2), pp. 129-136. ISSN 0279-5442. 
